\title{
Doença respiratória bovina em vacas persistentemente infectadas (PI) pelo vírus da diarreia viral bovina (BVDV)
}

Natália Meirelles Sobreira ${ }^{[]^{*}}$, Juliana França dos Reis Costa ${ }^{[a]}$, Camila Costa Baccili[a], Claudia Pestana Ribeiro ${ }^{[b]}$, Maristela Edviges Pituco ${ }^{[b]}$, Ricardo Araújo $0^{[c]}$, Rodrigo Hernandes ${ }^{[c]}$,Viviani Gomes ${ }^{[a]}$

\footnotetext{
[a]Faculdade de Medicina Veterinária e Zootecnia, Universidade de São Paulo (USP), São Paulo, SP, Brasil

[b] Laboratório de Viroses dos Bovinos, Instituto Biológico, São Paulo, SP, Brasil

${ }^{[c]}$ Fazenda Colorado, Araras, SP, Brasil
}

*Autor correspondente

e-mail: na_sobreira@usp.br

\section{Resumo}

As bezerras PI's geralmente nascem fracas e imunossuprimidas, tornando-as susceptíveis a um complexo de doenças que culmina na sua morte antes dos 2 anos de vida. 0 objetivo deste trabalho é relatar e alertar sobre a presença e perfil apresentado por vacas adultas em lactação PI's, provenientes de um rebanho leiteiro de alta produção com a média diária de 38,5L de leite. Foram colhidas amostras de tecido do pavilhão auricular oriundos de 3.444 animais para a realização do teste imunoenzimático direto (Bovine Virus Diarrhea Virus Antigen Test, Idexx), realizando-se o procedimento duas vezes, com intervalo de 30 dias. Foram detectadas oito vacas $(8 / 3444,0,23 \%)$ em lactação persistentemente infectadas. As vacas PI's foram avaliadas clinicamente através dos escores de saúde padronizado pela Universidade de WiscosinMadison no momento da colheita de material para o $2^{\circ}$ teste imunoenzimático. Os parâmetros tosse, secreção nasal, secreção ocular, posição orelhas e/ou cabeça e temperatura retal são classificados de 0 a 3 de acordo com a intensidade da manifestação clínica. 0 escore fecal foi classificado de 0 a 3 de acordo com a consistência das fezes. Além disso, foi realizada a soroneutralização para as viroses respiratórias. Em relação às broncopneumonias, detectou-se $1 / 8(12,5 \%)$ com a soma do escore respiratório igual a 4, e 4/8 animais (50\%) com soma dos escores $\geq 5$, sugerindo Doença Respiratória Bovina (DRB). No escore de diarreia, $5 / 8(62,5 \%)$ vacas apresentaram escore 1 e $3 / 8(37,5 \%)$, escore 2 . Todas as vacas eram soronegativas para o BRSV e BVDV tipo 1. Para o BVDV tipo 2, detectou-se 3/8 $(37,5 \%)$ vacas soropositivas, observando-se média dos títulos de anticorpos neutralizantes igual a $\log 10=0,60( \pm 0,89)$. Para o BPI3-V, detectou-se que $8 / 8(100 \%)$ das vacas eram soropositivas com títulos médios de anticorpos neutralizantes equivalentes a $\log ^{10}=1,99( \pm 0,51)$. As vacas também eram soropositivas para o BoHV-1 $(8 / 8,100 \%)$, com a 
titulação média de $\log ^{10}=1,95( \pm 0,53)$. A principal enfermidade apresentada pelas vacas PI's lactantes foi DRB, provavelmente associada à ausência ou baixo número de títulos de anticorpos neutralizantes para as viroses respiratórias. 